\title{
Bank Service Quality Dimensions in Developing and Transition Economies: The Case of Albania
}

\section{PhD candidate, Soniela Grazhdani}

"Fan S. Noli" University, Shëtitorja "Rilindasit", 7001, Korçë, Albania

Email: s.grazhdani@gmail.com

\section{Prof. Dr. Arben Vërçuni}

Agricultural University of Tirana, Tirana, Albania

Email: bvercuni@yahoo.com

$\mathrm{PhD}$, Klaudeta Merollari

"Fan S. Noli" University, Shëtitorja "Rilindasit", 7001, Korçë, Albania Email: klaudetamerollari2010@hotmail.com

Doi:10.5901/mjss.2015.v6n4p340

\begin{abstract}
The aim of this paper is to appraise bank service quality dimensions in developing countries and identify issues for future research based on the analysis of the literature. We browsed and search within the literature that have a focus on bank service quality measurements. We had three criteria for incorporation of a study : 1) it analysis issues related to bank customer perception and expectations, 2) it develops bank service quality measurements in different countries or culture and 3) it investigate the relationship between bank customer perception lexpectation with culture dimensions. We first give a theorical framework of western developed bank service quality construct and measurement. The variables used for these measurements were analyzed for relationship with cultural and economic factors and direction for strategy setting are highlighted. The patterns that emerge from literature review in other developing and transition economies give insight for the perception of bank service quality dimensions in Albania. The results in this research show that, while the dimensions use to define bank service quality may be similar in different countries, the relative importance and interpretation of the dimension differ from those find in studies conducted in developed economies. The relative importance and interpretation of service quality dimension in Albanian banking system are important to manager for service strategy generation, service development, pricing strategy, communication and service delivery and to researcher for developing bank service quality measurements.
\end{abstract}

Keywords: Service quality, Developing countries, Banking industry, Albania

\section{Introduction}

Several studies that examine the banking sector have found that culture influence service quality perception (Furrer, 2000; Witkowski and Wolfinbarger, 2000). Customers in different countries are expected to have different perception of what a service quality is because of differences that exist in term of economic development level, political and socio cultural system (Furrer, 2000; Witkowski and Wolfinbarger, 2000). Management must decide wich of the service element might be tailored to meet local need and expectations (Lovelock, 1999).

Banks in transition countries are following the path of the bank in developed countries while at the same they face specific challenges because of differences in their economic, political and cultural environment.

Hill and Kennington, 1996 investigated the "transferability" of western - style marketing in Polish banks and found that similar concept can be applied but require adaption within a specific context. One of these concepts is also service quality.

In these circumstances we first give a theorical framework of western developed bank service quality construct and measurement. The variables use for these measurements were analyzed for relationship with cultural and economic factors and direction for strategy settings are highlighted. The patterns that emerge from literature review in other developing and transition economies give insights for the perception and expectations of bank service quality dimensions in Albania. Reports from studies measuring bank service quality in Albania compared with finding in other countries are 
presented to determine if Albanian bank managers need to adopt different strategies.

International banking services are growing due to continuous technology innovation, increasing global deregulation and corporate consolidation. So, managers face a lot of challenges to manage the quality of service internationally as cross national customer differ in service quality expectation and perceptions. It is this study aim to analyze these differences and give recommendation for managers to adopt strategies that meet customer specific needs in developing countries. This study also gives recommendation for additional service quality determinants that researchers and academics must take into account when elaborating bank service quality measurement in developing countries.

\subsection{Theorical framework}

\subsubsection{Bank service quality dimensions}

The SERVQUAL model developed by Parasuram $(1985,1988)$ is the most cited and applied model for measuring service quality. The SERVQUAL model is composed by ten dimensions or determinants of service quality: reliability, access, understanding of the customer, responsiveness, competence, courtesy, communication, credibility, security, and tangible.

From reviewing the literature on the area of bank service quality measurements can be concluded that SERVQUAL was design as a universal scale applicable within and across a wide range of service settings has been used, replicated and modificated within specific banking sector.

To provide a lasting solution to the problem of the unsuccessful measurability of SERVQUAL, researchers agreed on a possible modification of the SERVQUAL model to suit the specific service settings (Bahia and Nantel, 2000; Jabnoun and Khalifa, 2005; Amin and Isa, 2008; Othman and Owen, 2001; Guo, Angus and Hair, 2008; Jabnoun and Al Tamimi, 2003; Obaid, 2006; Karatepe, Yavas and Babakus, 2005).

To build their BSQ retail banking - specific metric Bahia and Nantel (2000), modificate the SERVQUAL model. Bahia and Nantel (2000) used a number of the SERVQUAL dimensions and incorporated additional dimensions in order to cover all the facets of the marketing mix.

After modification, the dimensional structure of the BSQ scale was based on six dimensions effectiveness and assurance (which was composed from six SERVQUAL dimension competence; responsiveness; credibility; security; empathy; and communication), access, price, tangibles, service portfolio, reliability.

\subsubsection{Cultural Dimensions}

Several researchers have classified countries based on different cultural features (Hall, 1976; Hofstede, 1980; Hofstede and Bond, 1988; Schwartz, 1994, Steenkamp, 2001; Triandis and Gelfand 1998; Keillor, 1996; Trompenaars and Hampden-Turner, 1997) but it is Hofstede (1980) who offers a seminal work in operationalizing national culture. Hofstede's research work appears to be heavily relied upon because of its extensiveness across cultures and its intuitive appeal (Zhang, 2008). Hofstede (1980) identified four dimensions of national culture. These dimensions are: power distance, uncertainty avoidance, individualism/collectivism and masculinity/femininity.

Power distance indicate the extent to which the less powerful member of society expect and accept that power is distributed unequally (Hofstede, 1980). Power distance reflects the member inequality in areas such as social status, wealth, education level and occupation.

Uncertainty avoidance indicates the extent to which a society feels threatened by uncertain and ambiguous situations. Member in these societies have strong need for written rules and regulations (Hofstede, 1980).

Individualism/collectivism reflects people's attitude toward the group. In collectivist society people are integrated into strong cohesive in group. People are identified by their position in the social network to which they belong (Hofstede, 1991). Bolton and Myers (2003) propose that in collectivist society relationships between service firms and their customers are stronger and more loyal than in individualist society.

Masculinity reflects the extent to which the role of two genders is distinct in the society. Masculine societies put emphasis in differentiation of the role of genders; effectiveness, ambition and independence, while in feminine society represent fluid roles of genders, quality of life and interdependence (Hofstede, 1991).

\subsubsection{The cultural profile of Albanian society}

For drawing the cultural profile of Albania society we refer to Hofstede cultural dimensions scores (http://geerthofstede.com/albania.html). The range of scores runs from $0-100$ with 50 as midlevel. If a score is under 50 the culture 
scores relative low on that scale and if it is above 50 the culture scores relative high on that scale. Albania has considerable high scores above 50 for power distance at 90 , uncertainty avoidance at 70 and masculinity at 80 . Albania has a very low score under 50 for individualism at 20. Based on this scores the Albanian society can be described as a) that the power is and must be distributed unequally (Hofstede 1980), b) being a collectivist society offense leads to shame, hiring and promotion decision take account of the employee being a part of a in-group (http://geerthofstede.com/albania.html) c) being a masculine experiencing a high degree of gender differences d) having a low tolerance for uncertainty and a desire to control the future.

In Albania because of high uncertainty avoidance culture there is a need for rules (even if these rules never seem to work), security is an important element in individual motivation and decision are taken after careful analysis of all information (http://geert-hofstede.com/albania.html).

\section{Material and Methods}

We browsed and searched within the literature that have a focus on bank service quality measurements and on bank service quality measurements in different countries and culture. We had three criteria for incorporation of a study: 1) it analysis issues related to bank customer perception and expectations, 2) it develops bank service quality measurement in different countries or culture and 3) it investigate the relationship between bank customer perception /expectation with culture dimensions.

Because of limited number of service quality cross-culturally we decided to conduct a deep literature review in this topic as it would highlight the directions for future research.

\section{Results and Discussion}

We investigated the cross - cultural researches that relate Hofstede cultural dimensions and service quality perceptions and expectations with a focus in banking industry and in developing countries. This investigation draw out the following insights about SERVQUAL dimensions in developing countries.

Reliability - included in reliability dimension of BSQ model

Reliability involves consistency of performance and dependability. It means that firms perform the service right the first time and honors its promises (Parasuraman, 1985).

In developing countries, because of a wider zone of tolerance for ineffective service, emphasis should be put on "merely good" instead of "breakthrough" services (Malhotra, 1994). Merely good service is present in : a) collectivist culture where customer easily acquiesce and endure poor services as they do not wish to conflict or to stick out of the crowd (Balestrini, 2005) and b) in societies with large power distance, where weak customer are more likely to tolerate failure for more powerful services providers (Furrer, 2000).

Also, in developing countries the reliability can be better established with a relative emphasis on personnel than on technology (Malhotra, 1994).

Responsiveness - included in effectiveness dimension of BSQ model

Responsiveness means the employee willingness and readiness to respond to customer complaints and inquires in timely and substantive manner (Parasuraman, 1985).

In developing countries, where people are less driven by the clock, the concept of "promptness" is more flexible (Riddle, 1986). In these countries people have higher tolerance level for the content or timing of the services (Raajpoot, 2004). Collectivist cultures find it difficult to complaints and place higher value on organization-initiated recovery (Pasongsukarn, 2001; Muller, 2003).

Merely by responding to customer inquires or complaints in substantive manner without predetermined schedule is seen as satisfactory in developing countries (Malhotra, 1994). In developing countries, with high uncertainty avoidance the possibility of failure has to be reduced by handling the problem, therefore responsiveness is very important (Furrer, 2000).

Competence - included in effectiveness dimension of BSQ model

Competence means possession of required skills and knowledge to perform the service (Parasuraman, 1985).

In order to instill confidence and trust, in collectivist culture is important to emphas human interactions element of service such as knowledge of employee (Raajpoot, 2004).

In collectivist societies customer being no-self confident would demand for assurance. So, the service providers in this societies should emphasize training their employees to have professional knowledge (competence) (Furrer, 2000). In such collectivist societies the individual identity and skills of service employee are overshadowed by that of the service 
organization as a whole (Hofstede, 1991). So the competence of the service provider must be centralized in the organization as a whole (Malhotra, 1994).

Courtesy - included in assurance dimension of BSQ model

Courtesy involves politeness, respect, consideration and friendliness of contact personnel (Parasuraman, 1985). People in collectivist societies value harmony and avoid confrontation at all costs. Given their emphasis in relationship maintenance and harmony customer are highly sensitive to interpersonal treatments during service encounters (Hui, 2011).

In developing and collectivist countries service personnel should not abide by the widely accepted social norms and obligations of the societies, but also mirror their respect and commitment toward these norms (Brett and Okumura, 1998). Customers in large power distance see themselves in high position and will judge service employee's behaviour as an affront if they see an attitude of superiority (Straus, 1999)

Credibility - included in assurance dimension of BSQ model

Credibility involves trustworthiness, believability, honesty. It involves having the customer's best interests at heart. Company name, company reputation personal characteristics of the contact personnel, the degree of hard sell involved are the contributors for building credibility (Parasuraman, 1985).

Customers in collectivistic and/or high power distance cultures base their buying decisions more on feeling and trust in the company (De Mooj and Hofstede, 2010). These consumers collect their evidence more from endorsements of satisfied customers, brand and manufacturer's image (Malhotra, 1994). Customers from high uncertainty avoidance societies will show relatively greater preference for established brand name (Bianchi, 2001).

The service providers in developing countries should emphasize the company's long tradition and importance in the society in order to establish the credibility of the firm (Malhotra, 1995). A high context culture or a collectivist society values indirectness and a soft-sell approach (Singh, 2008).

Security - included in assurance dimension of BSQ model

Security is the freedom from danger, risk and doubt. It involves physical, financial security and confidentiality (Parasuraman, 1985).

In collectivistic and/or high power distance cultures, people will base their buying decisions more on feeling and trust in the company (De Mooj and Hofstede, 2002).

In societies with high uncertainty avoidance a desire for control, strong procedural quality strategies (Kettinger, 1995), superior warranty and money back guarantee (Bianchi, 2001) may be emphasis. There are three types of need: need for security (physical and financial), need for justice, and need for self-esteem (Schneider, 1999) It can be argued that in developing countries, consumers are at a lower order need (security) so the relative emphasis should be on physical and financial security (Malhotra, 1994).

Communication - included in assurance dimension of BSQ model

Communication means keeping customers informed in language they can understand and listen to them (Parasuraman, 1985).

Hofstede, 1980 found out that culture with high uncertainty avoidance experience greater stress and anxiety. This anxiety should inhibit the customer motivation to follow financial advice (Schumann, 2012). Many customers in developing countries still have to be informed and briefed about the functional aspect and benefits of the service (Malhotra, 1994).

In collectivistic and/or high power distance cultures, people will acquire information more via implicit interpersonal communication. Collectivistic cultures are high-context communication cultures, with an indirect style of communication (De Mooj and Hofstede, 2010). High-context communication cultures adopt less verbal communication modes such as facial expression (Hall and Hall, 1990). The propensity of collectivist societies to be reliant on word of mouth information and in particular the dominant role of family and social networks in choice behaviours has been examined (Money and Grill, 1998; Gregory, 2000; Smith and Chan, 1996).

In the developing countries, despite high intelligence, are prone to peripheral processing because poor information flow restricts their ability to use central processing. Non-business related informal communication and the quality of interaction form the basis of mutual understanding and trust (Harris, 1990; Riddle, 1992; Winsted, 1997).

The predominantly we consciousness associated with the collectivistic societies (De Mooij, 1998) is best handled by projecting the public benefits of the service as well as its acceptance by the society (Hofstede, 1980).

Understanding/knowing the customer - included in assurance dimension of BSQ model

Involves making the effort to understand the customer's needs. Part of this are learning the customer's specific requirements, providing individual attention and recognizing the regular customer (Parasuraman, 1985). In developing countries the relative emphasis is placed on understanding how the customer uses and derives benefits from the service 
(Malhotra, 1994).

Access - included in access dimension of BSQ model

Access involves approachability and ease of contact. It means convenient hours of operation, convenient location of service facility, waiting time to receive service (Parasuraman, 1985).

In establishing accessibility in developing countries the service provider should rely more on personal contact because the communication networks in these countries are limited and unreliable (Malhotra, 1994).

Tangibility - included in tangibility dimension of BSQ model

Tangibility includes the physical evidence of the service: physical facilities, appearance of personnel, physical representations of the service such as credit cards, bank statements etc (Parasuraman, 1985).

Customers in developing countries are generally satisfied with acceptable performance of the service in terms of the core benefits it promises to offer (Malhotra, 2005). In culture with large power distance tangibles help to maintain the distance and are important in the service quality evaluation process of weak customers (Furrer, 2000).

Characteristic such as intangibility, customer involvement and confidentiality are inherent to the products of most financial service provider (Salazar, 2007). Therefore, compared to other services, aspect such as risk, uncertainty, trust and personal relationship are important for customer behavior and the service quality perception (Mass, 2008).

In collectivist cultures customers are more tolerant of mistakes (Imrie, 2000, Kueh, 2007) and have lower expectations for reliability, but they evaluate more relationships and human interaction aspects of services such as the assurance (knowledge and courtesy of employees and ability to inspire trust and confidence) (Furrer, 2000; Kettinger, 1995; Raajpoot, 2004) and empathy (individualized attention and convenience) (Kettinger,1995).

\section{Conclusions}

\subsection{Service quality dimensions in Albanian banking system}

Service quality analyses in Albania banking system are important for several reasons. First, the findings can assist Albanian bankers, in refining their marketing strategies in compliance with cultural characteristics. Second, although no single country can be representative of all transition economies, the selection of a country/region in transition for study is important, as the research findings in one transition country may be reflective of others.

Until recently, Albanian banks tried to maintain their competitive standing via aggressive promotion and extensive branch networks (Lleshanaku. A, 2008).

There are disparities about interpretation and conceptualization of service quality dimension in different culture context. These disparities are used below for giving recommendation for service quality in Albanian banks. Taking into account the results from reviewing the literature about SERVQUAL and BSQ dimensions in developing countries we present some recommendations and conclusions for service quality dimensions in Albania.

\subsubsection{Price}

Level of economic development is undoubtedly a important factor that impacts price perception (Tse, Belk and Zhou, 1989). In Albania as in other developing countries customers may be persuaded to patronize the service on the base of marketing mix especially price discounts (Malhotra, 2005). The price in BSQ model refers to price in its specific monetary form and to price as a lack or delay of information. It is very important for Albanian customer better information on the offering (good explanations of service fees), term and condition due to poor information flow in Albania as a developing country.

\subsubsection{Service portfolio}

According to a study conducted by Glaveli (2006), service portfolio (which measures the range, innovation and consistency of services offered by banks) is the most important service quality dimension in Albanian banking system. This result may be related to a lack of bank services tailored to Albanian customer's needs. As it is evident in other transition countries the customers want improved bank offerings and a better targeting (Hill, 1996).

Tangible (includes precision of account statements, efficacious work environment, appearance of personnel and tools or equipments).

The lack of confidence might be also "responsible" for the relative importance of the tangible element of service quality. This could be achieved by stressing the bank's tangible element of the service as a way to highlight the credibility 
and the good image of the firm. Because Albania is a collectivist society emphasis should be put in core service aspects such as the precision of account statement.

\subsubsection{Access}

In building accessibility in developing countries is necessary to emphasize personnel contacts (Malhotra, 2005). Albanian would appreciate more convenience in banking. This can be achieved by longer opening hours and sufficient number of open tellers.

\subsubsection{Reliability}

Banks operating in Albania should rely more on consistency and dependability of the service personnel. There are two reasons for emphasizing personnel reliability in Albania. First, because Albania is a collectivist society where close and warm relationship between societies members are evident (Hofstede, 2001). Second, because Albania is a polychromic culture which typically focus more on human interactions such that time spent with other is considered a task because it helps build bonds that may be useful in the future (Kaufman,1991).

\section{Effectiveness and Assurance}

The impact of culture may also has affected the emphasis on the effectiveness dimension (which include competence, responsiveness) (Glaveli, 2006) since people in polychromic and collectivist societies stress the involvement of people and seldom experience time as "wasted" (Usunier, 1991; Hall, 1976).

- Competence: In high uncertainty avoidance societies customer build trust to a large extent based on a capability process and through appraising of expertise, so employee competence is another important dimension for Albania.

- Responsiveness: In Albanian as in other collectivist society the maintenance of social harmony is important therefore courteous, formal and empathetic manner recovery behaviours are more significant that compensation (Mattila, 2004). Also, because of collectivism, organization-initiated recovery (Pasongsukarn, 2001; Muller, 2003) should be emphasized.

As Albania is a high in uncertainty avoidance society they prefer to have everything in control therefore constant notification about the recovery process is essential (Mattila, 2004).

- Security: The lack of confidence in the banking system due to the recent developments, would demand from banks to inspire a feeling of security. There are still serious concerns among Albanian customers related with the safety and security of banks due to the scandals, financial difficulties and crisis in the industry. The Albanian banking system experienced a severe crisis in 1997 due to fall of the pyramid schemes. The 1997 experience made people quite sensitive to the risk of losing their deposits. Advertising and promotion in Albania should target the lower order needs, physical and financial security as recommended by Malhotra for developing countries.

- Credibility: Customers in collectivistic and/or high power distance cultures base their buying decisions more on feeling and trust in the company (De Mooj and Hofstede, 2010). Fair treatment in high uncertainty avoidance societies would build confidence and trust. Fair treatment is an important factor in Albanian banking system due to negative experiences like frauds and financial systems crisis. Trust would be damaged if customers expectations based on the past experience differ with the actual outcome (Zhu, 2009).

So, in building the corporate image banks in Albania should emphasize their long tradition (Malhotra, 2005) and fairness in procedure and information.

- Communication: Explicit service promise as advertising, personal selling, contracts, company brochures and other form of communication (Berry, 1991) need to be clear and stable in Albania in order to reduce uncertainty. As mention earlier in high uncertainty avoidance societies decision are taken after careful analysis of all information. There is less tolerance and acceptance for unclear situation and a strong need for consensus and clarity in these societies (Hostede, 2001). Therefore improvements that provide clearer explanation, more consistent services and easier to understand rules (Zhu, 2009) would increase security and build trust.

Albanian bank customer do not have a long experience in use of personal banking services and therefore is necessary to give a complete information about bank services and products. As stated by Malhotra, many customer in 
developing countries still have to be informed about the functional aspect and benefit of the services.

Manager should train their employee to have enough knowledge about the services to make the customers fully understand the service.

Albanian as a culture with high uncertainty avoidance experience greater anxiety because of ambiguity (Hofstede, 1980). This anxiety that dominate the society inhibit the customer motivation to follow financial advice (Schumann, 2012). Therefore, we have to consider this factor in measuring the service quality in Albanian banks.

In collectivist societies like Albania, the quality of communication would be lower. Employees in these societies have a propensity to convey information as quickly and as efficiently as possible without paying attention to the individual and diverse service needs of customers (Gnanlet, 2013). Also, in high power distance culture as Albanian culture because of employee and service provider belief of superiority the communication/information delivery follow strict lines without deviation from protocol (Gnanlet, 2013).

Banks in Albania provide limited or unclear information about services. In these circumstances banks should be capable of delivering the promise and have good intention to keep the promise in order to maintain trust (Zhu, 2009). Improved communication (i.e. information about products, conditions etc), keep customer informed of exactly what is done and professionalism of bank employee are very important factors for building banks service quality in Albania.

Keeping the customer informed over bank services through brochures, advertising and employee in a language that is easy and simple to understand is necessary for reducing the ambiguity in Albania and increasing the security.

- Courtesy: In collectivist society customers will value harmony and status (Winsted,1997) and will be highly sensitive to interpersonal treatments during service encounters (Hui, 2011). Therefore in Albania courtesy as aspect of service delivery can be expected to be of greater importance due to high score of collectivism. Customer in large power distance, see themselves in high position and will judge service employee's behaviour as an affront if they see an attitude of superiority (Straus, 1999). So, Albania managers must train their employees to be polite, respectful, friendliness and to give efficient treatment to customers.

- Understanding the customer: It is expected for Albanian collectivist customer, to be reluctant in insisting or negotiating because this is embarrassing and do not promote harmony as stated by Winsted (1997). Therefore, employees have to do their best to understand the specific needs of the client and show that they have its best interest at heart.

In order to reduce the insecurity associated with the development of Albanian banking, manager should insist to deliver exactly the way it is promised. The high level of uncertainty avoidance in Albanian culture would demand from bank employee to have enough knowledge and show a sincere interest in solving customer problem.

As a result, bank managers before developing quality strategies they need to consider customer demands, needs and expectations in different cultural environments. Future research should look to empirical test the recommendations and conclusions drawn out from this literature review to further validate this study.

Despite limitations currents results are important for managers in understanding service operationalization, pricing and communication strategies in developing and transition countries, similar to Albania.

\section{References}

Adelina Gnanlet, H. Muge, Yayla-Kullu (2014). Impact of national culture on the quality of information delivery in services. Service Business : An International Journal. Vol 8, Nr. 1, p. 135-169

Amin, M. and Isa, Z. (2008). An examination of the relationship between service quality perception and customer satisfaction. International Journal of Islamic and Middle Eastern Finance and Management, 1 (3), pp. 191-209.

Anna S Mattila and Paul G Patterson (2004). Service Recovery and Fairness Perceptions in Collectivist and Individualist Contexts. Journal of Service Research 6(4):336

Bahia, K. and Nantel, J. (2000). A reliable and valid measurement scale for the perceived service quality of banks. International Journal of Bank Marketing, 18 (2), pp. 84-91.

Bianchi, Constanza (2001). The Effect of Cultural Differences on Service Encounter Satisfaction. In Proceedings 2001 AMA Winter Educator's Conference 12, pages pp. 46-52, Scottsdale, Arizona.

Carman, J. M. (1990) Consumer perceptions of service quality: an assessment of the SERVQUAL dimensions. Journal of retailing, 66 (1), pp. 33-55.

Donthu, N. and B. Yoo (1998). Cultural Influences on Service Quality Expectations. Journal of Service Research, 1 (2), $178-86$.

Furrer, O., B.S. Liu, and D. Sudharshan (2000). The Relationships Between Culture and Service Quality Perception: Basis for CrossCultural Market Segmentation and Resource Allocation. Journal of Service Research, 2 (4), 355-71.

Glaveli, N., Petridou, E., Liassides, C. and Spathis. C. (2006) Bank service quality: evidence from five Balkan countries. Emerald Group Publishing Limited, 16 (4), pp. 380-94.

Guo, X., Duff, A. and Hair, M. (2008). Service quality measurement in the Chinese corporate banking market. International Journal of 
Bank Marketing, 26 (5), pp. 305-27.

Hofstede, G. (1980). "Culture's Consequences: International Differences in Work-related Issues". Sage, Beverly Hills, CA.

Hofstede, G.H. (1991). Cultures and Organizations: Software of the Mind. New York: McGraw-Hill.

Hofstede, G.H. (2001). Culture's Consequences: Comparing Values, Behaviors, Institutions, and Organizations Across Nations. 2d ed. Thousand Oaks, CA: Sage Publications.

Hong and Lee (2014). The influence of national culture on customers' cross-buying intention in Asian banking services - evidence from Korea and Tawain. New York : Routledge, p.30

Imrie, B.C., Durden, G.R., and Cadogan, J.W., (2000). Towards a conceptualization of service quality in the global market arena. Advances in International Marketing. Supplement 1, p.143 - 162.

Jabnoun, N. and Al-Tamimi, H. A. H. (2003). Measuring perceived service quality at UAE commercial banks. International Journal of Quality and Reliability Management, 20 (4), pp. 458-472.

Jabnoun, N. and Khalifa, A. (2005). A customized measure of service quality in the UAE. Managing Service Quality, 15 (4), pp. 374-88.

Jan H. Schumann, Nancy V. Wünderlich, Marcus S. Zimmer (2012). Culture's Impact on Customer Motivation to Engage in Professional Service Enactments. Schmalenbach Business Review, Vol. 64, issue 2, 141-165

Karatepe, O. M., Yavas, U. and Babakus, E. (2005). Measuring service quality of banks: scale development and validation. Journal of Retailing and Consumer Services, 12 (5), pp. 373-83.

Kennington, C. and Hill, J. (1995). "Marketing strategies in consumer banking in Poland". presented to the 3rd Annual Conference on Marketing Strategies for Central and Eastern Europe, Vienna, November, in conference Proceedings.

Kennington, C. and Hill, J. Rakowska, A. (1996). Consumer selection criteria for banks in Poland. International Journal of Bank Marketing 14(4), 12-21.

Malhotra, N., F. Ugaldo, J. Agarwal, and I. Baalbaki (1994). International Services Marketing: A Comparative Evaluation of the Dimensions of Service Quality in Developed and Developing Countries. International Marketing Review, Vol.11(2), 5-15.

Mattila, A.S. (1999). The Roles of Culture and Purchase Motivation in Service Encounter Evaluations. Journal of Services Marketing, 13 (4-5), 376-89.

Othman, A. and Owen, L. (2001). Developing an instrument to measure customer service quality SQ in Islamic banking. International Journal of Islamic Financial Services, 3 (1), pp. 1-26.

Parasuraman, A., V.A. Zeithaml, and L.L. Berry (1985). A Conceptual Model of Service Quality and Its Implications for Future Research. Journal of Marketing, 49 (Autumn), 41-50.

Parasuraman, A., V.A. Zeithaml, and L.L. Berry (1988). SERVQUAL: A Multiple Item Scale for Measuring Consumer Perceptions of Service Quality. Journal of Retailing, 64 (1), 12-40.

Parasuraman, A., V.A. Zeithaml, and L.L. Berry (1994). Reassessment of Expectations as a Comparison Standard in Measuring Service Quality: Implications for Further Research. Journal of Marketing, 58 (January), 111-24.

Pierre P. Balestrini, Fangbing Huo (2005). Cross-Cultural Service Quality Expectations in the Retail Banking Sector: A Study of Chinese and British Customers. ANZMAC Conference: Marketing Issues in Asia

Powell, W.W. and P.J. DiMaggio (1991). The New Institutionalism in Organizational Analysis. Chicago: University of Chicago Press.

Schumann, J. H., Wangenheim, F., Yang, Z., Jinenez, F., Komor, M., Praxmarer, S. \& Shainesh, G. (2007). Cross-cultural differences in the development of trust in relational service exchange - an empirical analysis of the moderating role of uncertainly avoidance. 4th Workshop on Trust Within and Between Organisations (pp. 1-31). Brussels, Belgium: The European Institute for Advanced Studies in Management (EIASM).

Shemwell, D.J., Yavas, U. and Bilgin, Z. (1998). Customer-service provider relationships: an empirical test of a model of service quality, satisfaction and relationship-oriented outcomes. International Journal of Service Industry Management, Vol. 9 No. 2, p. 155.

Smith, A.M. and Reynolds, N.L. (2002). Measuring cross-cultural service quality: a framework of assessment. International Marketing Review, Vol. 19 No. 5, pp. 450-81.

Speece, M. and Srijumpa, R. (2002). Touch still the ticket in developing areas. Marketing News, Vol. 36 No. 9, p. 39.

Steenkamp, J.-B. and H. Baumgartner (1998). Assessing Measurement Invariance in Cross-National Consumer Research. Journal of Consumer Research, 25 (June), 78-90.

Ting Lee Hui, Boo Huey Chern, Mohhidin Othman (2011). Development of service quality dimensions in Malaysia - the case of a multicultural society. Segi Review, Vol. 4, No. 1, p. 93-108

Triandis, H.C. (1995). Individualism and Collectivism. Boulder, CO: Westview.

Winsted, K.F. (1997). The Service Experience in two Cultures: A Behavioral Perspective. Journal of Retailing, Vol. 73 No. 3, pp. 33760.

Yu-Qian Zhu, Houn-Gee Chen (2009). Uncertainty Avoidance as a moderator to Service Fairness and Customer Satisfaction, The 4th Knowledge Management Conference in Organizations

Zeithaml, V.A., L.L. Berry, and A. Parasuraman (1996). The Behavioral Consequences of Service Quality. Journal of Marketing, 60, p. $31-46$. 